\title{
Australia and the Zero Lower Bound on Interest Rates: Some Monetary Policy Options
}

\author{
Declan $\operatorname{Trott}^{1}$
}

\section{Abstract}

This paper argues that Australia needs a contingency plan for monetary policy when interest rates hit zero, and considers various options. Level targeting appears undesirable as a long-run policy due to the lack of an appropriate target variable - prices, wages and nominal GDP all being unsuitable - but may be useful as a temporary expedient. Other possibilities include a higher inflation target and temporary exchange rate targeting.

\section{Could 'it' happen here?}

Australia survived the global financial crisis relatively unscathed, despite much higher interest rates than in other developed countries (see Figure 1). But our exceptional status may be short-lived. In May 2015, the cash rate was cut to 2 per cent, the lowest level since the current series began in 1990, and by some measures the lowest short-term rate since at least 1960. Nevertheless, unemployment has risen steadily, despite the fact that investment in the resources sector has yet to fall back to normal levels.

\footnotetext{
1 declan_t@hotmail.com. Thanks to Greg Connolly, William Coleman and an anonymous referee for comments. This paper has also been greatly benefitted by Scott Sumner's blog 'The Money Illusion' and Nick Rowe's blog 'Worthwhile Canadian Initiative'.
} 


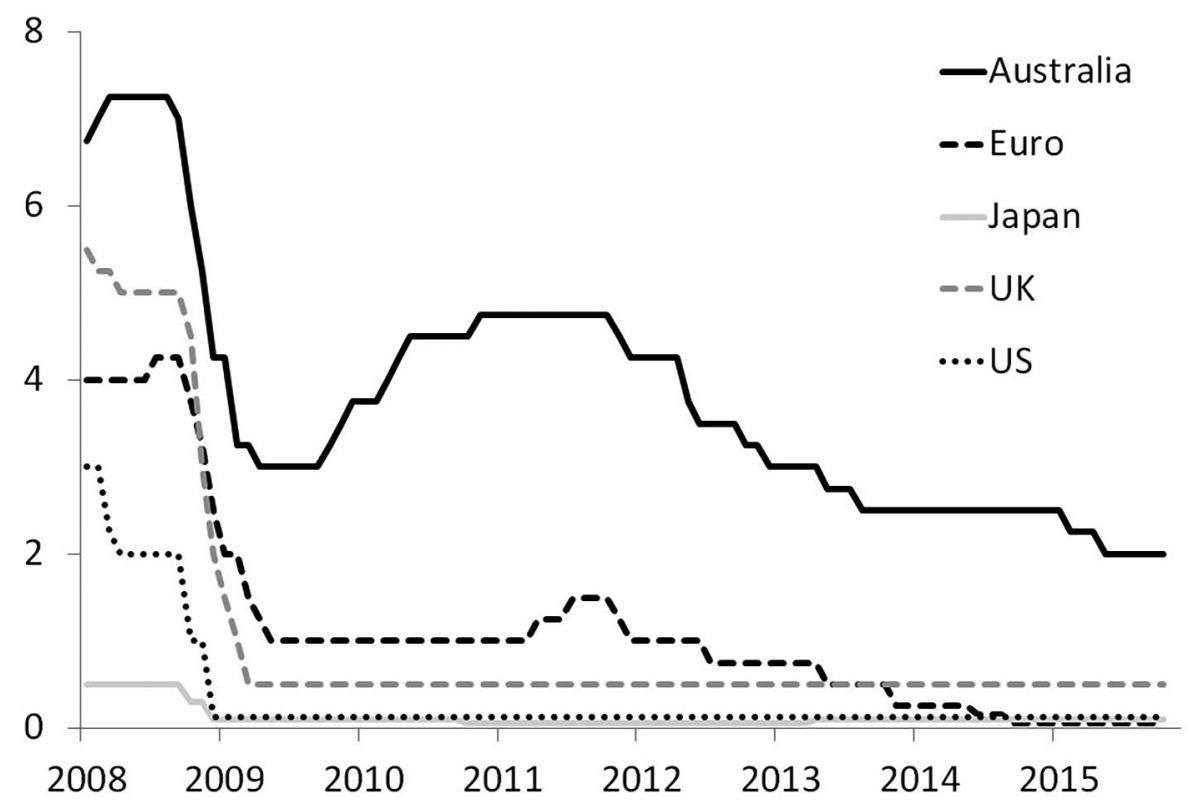

Figure 1: International official interest rates, \% p.a.

Source: Reserve Bank of Australia, Statistical Bulletin, table F13

It would seem prudent, then, to be prepared for interest rates to approach zero, as has already occurred in most other OECD countries. ${ }^{2}$ Sheehan and Gregory (2013) and Freebairn and Corden (2013) have called for increased infrastructure spending on this basis. Yet, as these authors acknowledge, such a policy faces considerable challenges. Furthermore, if warnings of 'secular stagnation' have any validity, near-zero interest rates may not be a once-in-a-generation emergency to be dealt with using ad hoc expedients, but an increasingly common situation requiring a more systematic response. In this case, changes to monetary policy would appear more desirable.

This paper considers various means by which monetary policy may stimulate aggregate demand when its usual instrument - the short-term interest rate - is unavailable. The objectives of monetary policy are taken here to be the conventional ones of a stable value of money and full employment, analysed

2 Of the 40 member countries listed (counting the Eurozone as 19 separate countries) in OECD.Stat Monthly Monetary and Financial Statistics, 31 have experienced at least one month with 'Immediate interest rates, Call Money, Interbank Rate' less than 0.5 per cent p.a. since 2008. 
under the broadly 'Keynesian' assumption that fluctuations in nominal spending have significant effects on real output. Financial stability objectives are assumed to be dealt with separately via (macro)prudential regulation. ${ }^{3}$

The paper begins by describing the problem of the zero lower bound, and the logic of expectations management in general and level targeting in particular as a solution. It then argues, however, that level targeting requires a more careful choice of target variable than the current regime of inflation targeting, and that the price level, nominal GDP and nominal wages all appear problematic. A more eclectic mix of policies is then considered.

\section{The zero lower bound, and the vital role of expectations}

As long as money can be stored at negligible cost, interest rates cannot fall below zero, because hoarding money would then be a superior alternative to lending it. This poses a problem for conventional monetary policy, under which the usual response to falling inflation or rising unemployment is a lower interest rate. What happens if the interest rate cannot be cut any further? The experience of Japan in the 1990s, and much of the world since 2008, shows that near-zero interest rates are perfectly compatible with low and falling inflation, high and rising unemployment, and output well below previous estimates of potential.

Can monetary policy still be effective in such a situation? Theory suggests that expectations management is the key. In the standard permanent income or life-cycle model, current spending is determined by expected future income and interest rates. If promises about future policy are successful in changing these expectations, they may increase demand without any immediate change in the central bank's balance sheet. Conversely, even a very large balance sheet expansion may be ineffective if it is believed to be temporary and thus does not change expectations. ${ }^{4}$ Krugman (1998), motivated by the then unusual experience of Japan, showed that, while a temporary monetary expansion would fail to raise prices and output at the zero lower bound (since it cannot change the current interest rate, and, being temporary, will not affect any future variables), a credible permanent expansion could work, by increasing

\footnotetext{
3 While this separation is potentially controversial, it is the author's opinion that the alternative a willingness to tighten monetary policy in the face of a perceived asset or credit bubble, despite benign or below-target inflation and employment outcomes - is more risky, assuming not only the ability to secondguess market pricing, but that the blunt instrument of aggregate demand restriction is preferable to more targeted measures directed at the 'bubble' sector. Furthermore, if low nominal interest rates are considered dangerous, a tight money policy would tend to worsen the problem in all but the very short run by creating lower inflation (the Fisher effect), as the recent experience of Sweden illustrates.

4 The actions of Japan's central bank in the 2000s, and the Swiss more recently, come to mind.
} 
the expected future price level and therefore reducing the real interest rate. (This assumes that a permanently higher money supply must eventually create proportionally higher prices at some point in the future when the interest rate rises above zero.) Sumner (1993) made a similar point, though without reference to the zero lower bound, when he argued that a large but temporary increase in the money supply would not have a proportional effect on the price level, in the context of colonial American note issue.

Combining promises about future policy with additional action in the present may be desirable both as a signal to make the promises credible, and to overcome problems not accounted for in the simple life-cycle model, such as credit constraints and adaptive or backward-looking expectations. Thus, Svensson (2003) argues that optimal policy at the zero lower bound involves three elements: commitment to a higher future price level, concrete action to demonstrate this commitment, and an exit strategy. Similarly, Woodford (2012: 87) advocates 'a combination of commitment to a clear target criterion ... with immediate policy actions that should stimulate spending'. Such action might include fiscal stimulus, exchange rate intervention, or central bank asset purchases, some of which are discussed below.

\section{Target the level, not the rate?}

Repeated mention of the future price level leads naturally to consideration of level targeting. Price level targeting is identical to inflation targeting - more generally, targeting the level of any index is equivalent to targeting its rate of change - as long as the target is hit in every period. A price level target increasing by 2 per cent p.a. and a 2 per cent inflation target both imply that, if the current price level is 100, it should be 102 next year, and 104 the year after that. But under inflation targeting, there is no subsequent correction of mistakes. If actual inflation in the first year is only 1 per cent, giving a price level of 101, the inflation target implies a new target price level of 103 for the year after. Under level targeting, by contrast, the target price level remains at 104, implying a temporary rise in inflation to 3 per cent to make up for the previous undershooting.

This difference has important implications for real interest rates. The zero lower bound is associated with low and falling inflation, both because low inflation reduces the target interest rate, and because the zero lower bound forces real interest rates to be higher than desired, causing further disinflation. Under inflation targeting, the best case is that inflation is expected to return to target quickly, so that expected real rates remain stable. In the worst case, inflation expectations become unanchored, leading to a death spiral of higher real rates 
and disinflation. Under a credible level target, exactly the opposite effect occurs. Lower inflation today implies higher inflation tomorrow, cutting expected real rates.

Expectations of real income, as well as interest rates, also play an important role, and can magnify the effects of successful policy. As Romer (2013: 2) puts it:

... if aggressive monetary policy actions can cause expectations of real growth, this may have an even greater impact on consumer spending and investment. Consumers who expect to have a job are far more likely to buy cars and remodel their kitchens than those who do not. And firms that expect to have customers are far more likely to build new factories and buy new machines than those that do not.

She describes the 'regime shift' that occurred in the United States in 1933, when the Roosevelt administration suspended the gold standard and announced an intention to reflate commodity prices to their pre-Depression levels. ${ }^{5}$ Stock prices and expected inflation rose dramatically and industrial production increased 57 per cent in four months, despite fiscal contraction and a national banking holiday.

This period of history offers other relevant examples. Crafts (2013) argues that British monetary policy after going off the gold standard in 1931 de facto followed a price level target. Sweden, however, may be the only country to adopt a de jure price level target (also in the 1930s), as described in Berg and Jonung (1999). Both of these countries achieved relatively rapid recoveries from the Great Depression following their monetary regime changes.

While this paper focuses on level targeting's effectiveness at the zero lower bound, this is not the only argument in its favour. Woodford (2003: 498, 501) finds that price level targeting can be optimal, and in a much wider set of cases, optimal monetary policy displays some history dependence - that is, past errors are partially, but not completely, corrected - even if policymakers care only about the inflation rate (as opposed to the price level) and the zero lower bound is irrelevant. While it is optimal ex post to allow bygones to be bygones, ex ante it is worthwhile to have some commitment to reversing over- or undershooting, because it will moderate price setters' response to a given shock.

5 See www.popmodal.com/video/2066/Vintage-pro-inflation-propaganda. 


\section{Alternative target variables: Nominal GDP and nominal wages}

While both the theory and history of level targeting make it appear promising as a means of escape from the zero lower bound, there are questions over its suitability as a permanent policy regime. In particular, idiosyncratic shocks to the price level - that is, shocks that are uncorrelated with the output gap, or 'supply shocks' - pose a much greater problem under level targeting. Under inflation targeting, it is standard practice to 'look through' shocks such as tax changes or commodity price fluctuations. For example, in 2011 the Bank of England estimated that sterling depreciation, higher energy prices and rising VAT would generate a 12 per cent rise in the UK price level, and decided that these 'temporary shocks' should be accommodated rather than reversed by monetary policy (HM Treasury 2013: 24). Level targeting does not permit this, and if these shocks are persistent, they will require costly fluctuations in output to hit the target. Coletti et al. (2012), for example, find that persistent commodity price shocks make price level targeting inferior to inflation targeting, a finding that is highly relevant to Australia.

If the price level is an unsuitable target, what other options are there? It is widely agreed that monetary policy targets should be wholly or partly nominal, since a purely real target such as output or unemployment may be unattainable and, in any case, leaves nominal values such as the price level indeterminate. Mankiw and Reis (2003) and the Bank of England (2013: 23) agree that a good target should be procyclical - 'a good guide to the broad economic conditions' - and have low exposure to idiosyncratic shocks - not 'likely ... to provide a misleading signal'. Two variables often suggested as an alternative to the CPI are nominal GDP and nominal wages.

Nominal GDP has several appealing features. It neatly combines the twin goals of price and output stability, without relying on unobservable variables such as the output gap, and avoids the quality-adjustment problems of price indices. As 'nominal income' or 'national income' targeting, it enjoyed some academic popularity in the 1980s and early '90s, although it was never adopted by a central bank. ${ }^{6}$ Interest in the concept then waned due to the widespread adoption of inflation targeting, and also because research did not show any clear advantage. In an Australian context, for example, both McKibbin (1997) and de Brouwer and O'Regan (1997) found that an interest rate rule responding to inflation

\footnotetext{
6 For a brief history, see content.ksg.harvard.edu/blog/jeff_frankels_weblog/2012/06/13/nominal-gdptargeting-could-take-the-place-of-inflation-targeting/.
} 
and the output gap outperformed a nominal income rule. Orphanides (2003), however, came to the opposite conclusion using US data, when measurement error in the output gap is taken into account.

After 2008, nominal GDP targeting experienced renewed popularity. Level targeting was seen as a way to overcome the zero lower bound, and nominal GDP showed the effects of the recession in the US and Europe much more clearly than the price level did. ${ }^{7}$ This resurrection was led by 'market monetarist' bloggers such as Scott Sumner, but has since received endorsement from Romer (2011) and Mishkin and Woodford (2013) in the United States, and Quiggin (2012) and McKibbin (2015) in Australia.

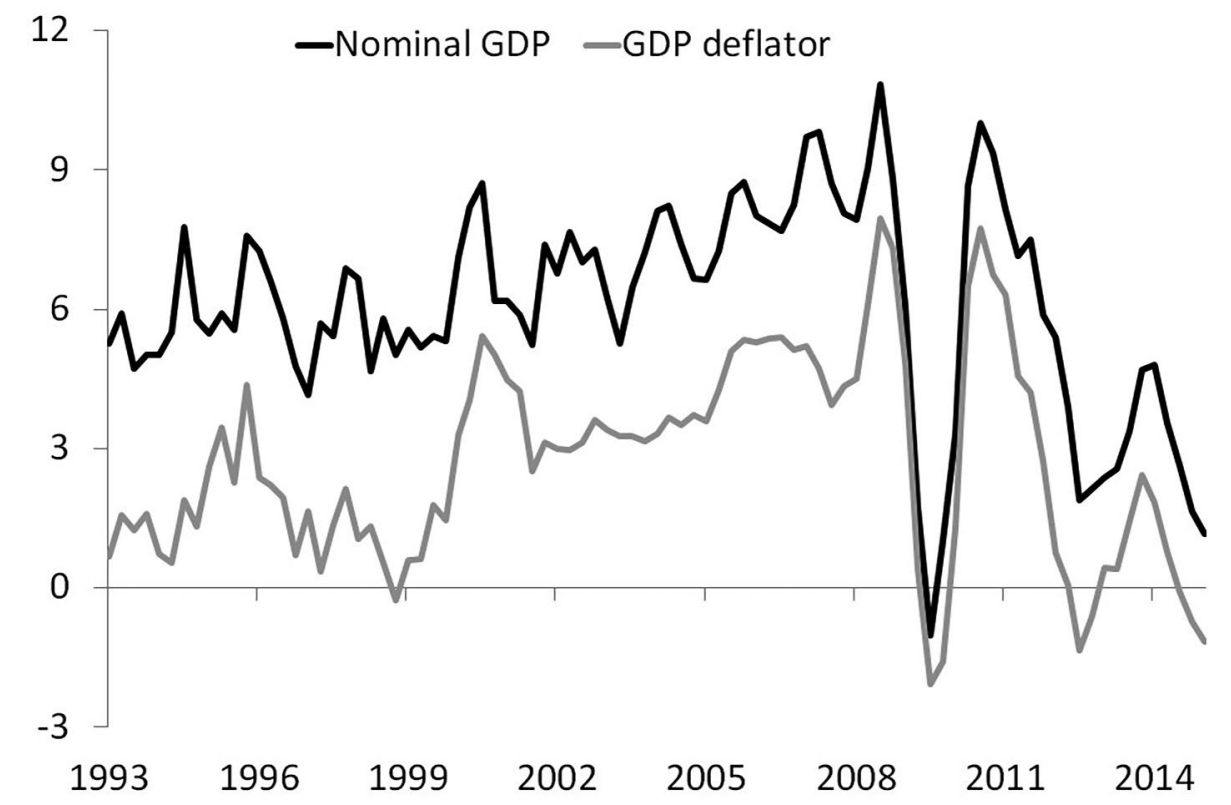

Figure 2: Growth in nominal GDP and GDP deflator, \% year-ended

Source: Reserve Bank of Australia, Statistical Bulletin, table H1 \& author's calculations

The historical behaviour of Australian nominal GDP, however, appears to make it an unsuitable target for monetary policy. Figure 2 shows the growth rates of nominal GDP and the GDP deflator. After being fairly stable at around 6 per cent p.a. in the 1990s (with a spike when the GST was introduced), nominal GDP growth began to accelerate in the early 2000s, peaking at over 11 per cent in the year to 2008 Q3. It then fluctuated wildly, actually turning negative in 2009, before rising and falling again. Most of these gyrations were due to the GDP deflator rather than real GDP (the gap between the two series). It therefore

7 While some view this lack of deflation as evidence that the output gap was never very large, others argue that inflation becomes very sticky at low rates, due to nominal wage rigidity (see below). 
seems plausible that they represent idiosyncratic shocks rather than procyclical movement - that is, that the extreme high and low growth rates of nominal GDP did not represent a correspondingly high or low output gap. ${ }^{8}$

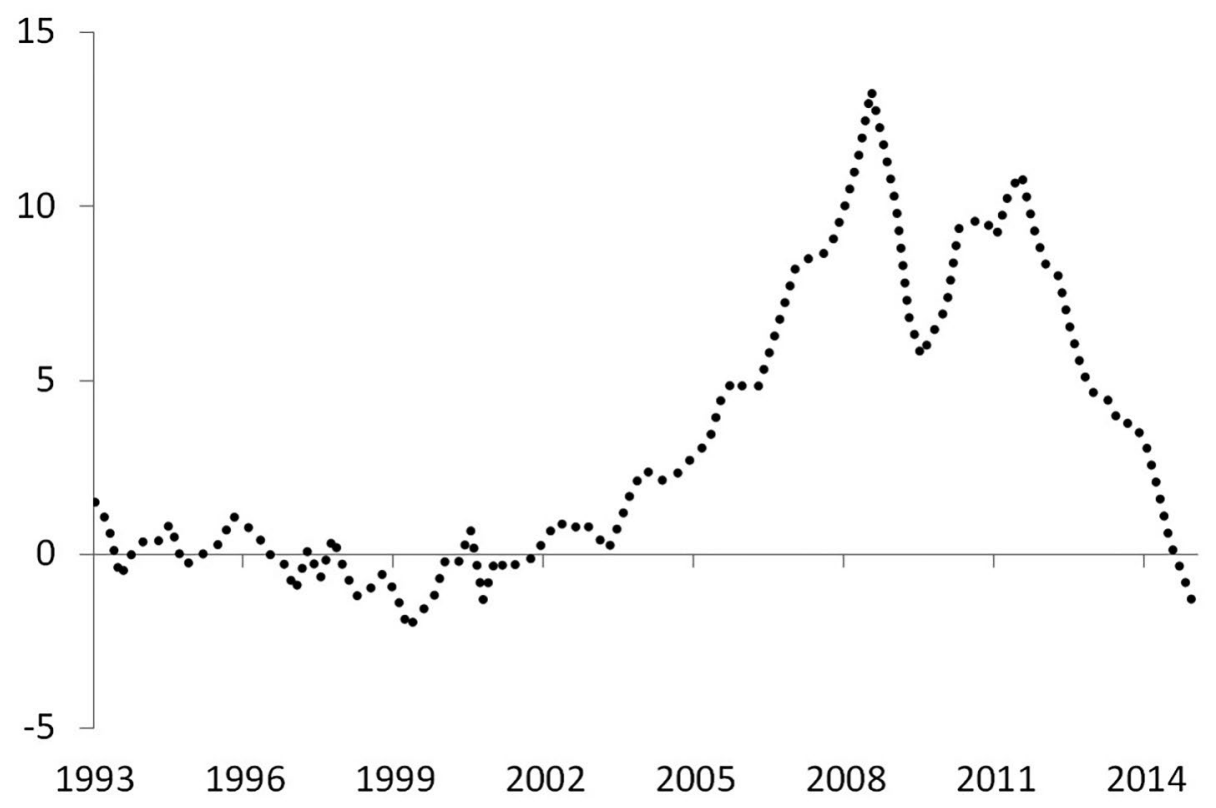

Figure 3: Nominal GDP, \% deviation from 1993-2003 trend

Source: Reserve Bank of Australia, Statistical Bulletin, table H1 \& author's calculations

Figure 3 shows the deviation of nominal GDP from an OLS exponential trend line fitted to 1993-2003 data. This time period is chosen to represent typical conditions under the current inflation target, between the end of the 'recession we had to have' and the beginning of the mining boom, and yields a 6.1 per cent p.a. trend growth rate (consistent with roughly 3.5 per cent real growth and 2.5 per cent inflation). Nominal GDP was above this trend continuously for over 12 years starting in 2002, peaking at over 13 per cent above it during 2008, and only falling below it in the last quarter of 2014.

Clearly, actual monetary policy since 2003 is poorly described by a nominal GDP target, whether in growth rates or levels. It might be argued that policy during this period was actually far too loose, and that keeping on the previous trend line would have been appropriate. There was, however, little sign that the economy was overheating. As Figure 4 shows, while the headline CPI exhibited several fluctuations due to the introduction of the GST and various

8 The latest (November 2014) OECD estimates of the output gap are 1.9 per cent for 2007 and 1.1 per cent for 2008 , but the contemporary (December 2008) estimates were only 1.0 per cent and 0.3 per cent respectively (Economic Outlook nos 96 and 84). 
fuel and food price shocks, the trimmed mean did not rise significantly above the 2-3 per cent target band until 2008. Even this late spike in price inflation was not reflected in wages. Growth in the wage price index (WPI) was almost completely stable at just over 4 per cent during the peak of nominal GDP growth from 2005-08. Strikingly, there was also no recession when the period of rapid nominal growth ended.

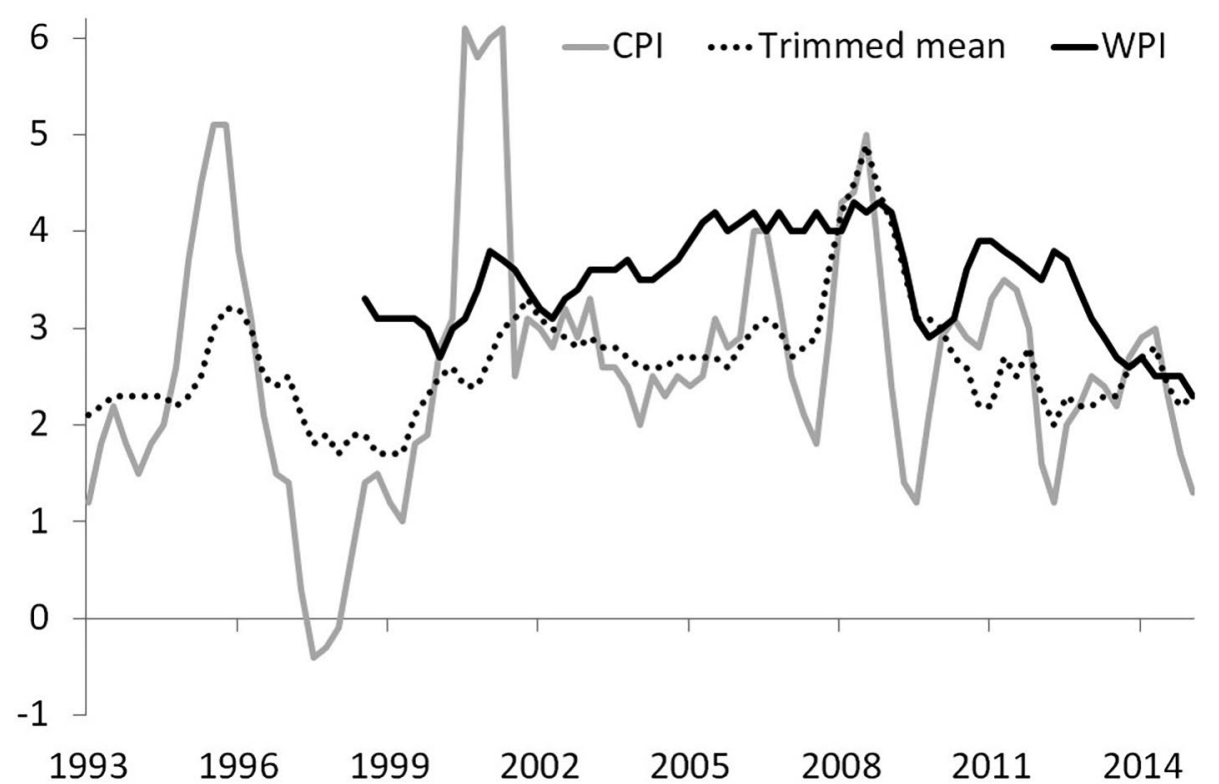

Figure 4: Price and wage inflation, \% year-ended

Source: Reserve Bank of Australia, Statistical Bulletin, tables G1 \& H4

Counterfactually, consider what sticking to the 6.1 per cent p.a. trend growth rate of 1993-2003 would have entailed in 2008. Nominal GDP growth would have been five percentage points lower. For all real variables to remain unchanged, nominal wages would have had to fall by 1 per cent rather than rise by 4 per cent. This seems implausible. Alternatively, real output and employment would have been lower, which seems unnecessary and undesirable given stable wage growth.

Nominal wages are another possible target. Sumner (1995) describes proposals for nominal wage targeting dating back to the early nineteenth century. Mankiw and Reis (2002) find that wages are more procyclical and suffer smaller idiosyncratic shocks than the CPI. Other studies (for example, Erceg et al. 2000; Canzoneri et al. 2005; Givens 2009) also find that nominal wages perform well as a target, either on their own or as part of a composite index. 
Yet nominal wages may present unique dangers as a formal target. There is a large literature documenting downwards nominal wage rigidity - workers are reluctant to accept (and employers reluctant to impose) absolute nominal wage cuts (for example, Kahn 1997; Bewley 1999; Dickens et al. 2007). It is harder to reduce nominal wages by 2 per cent when prices are stable than to keep them constant when prices rise by 2 per cent.

This might seem to be an argument in favour of a reasonably high target for nominal wage growth. Yet it is also a reason for caution. In the spirit of Goodhart's Law, it seems reasonable to speculate that, if an explicit wage target was adopted, this target would become the new norm for wage setting. Some downward stickiness could easily transfer itself from zero to the target rate. Under, say, a 4 per cent p.a. wage target, it might take very high unemployment to force wage growth below 4 per cent. Moreover, as there is no equivalent evidence for upwards nominal wage rigidity, it might not take a very tight labour market for aggregate wage growth to rise above target, particularly if conditions in different sectors of the economy were not uniform. While the weaker sectors would be constrained by the 4 per cent lower bound, there would be nothing preventing wages in the stronger sector from rising faster. By turning nominal wages into a policy target, they might cease to be a good indicator of the state of the economy, and hitting the target might require a permanently elevated rate of unemployment.

Some close relation of nominal GDP or the WPI might do a better job, much as core measures of inflation are used to alleviate the weaknesses of the headline CPI. The ideal would be a nominal income measure that was less subject to terms of trade and other shocks, or an index which behaved similarly to nominal wages without providing a focal point for wage rigidity.

A preliminary investigation did not turn up any promising candidates on the income side. While it was hoped that they might have been less affected by the terms-of-trade boom, nominal non-mining GDP, gross national expenditure (gross domestic product less net exports), and compensation of employees (all at current prices) behaved in a very similar way to nominal GDP. ${ }^{9}$ The alternative measures of labour costs considered by the Reserve Bank of Australia (RBA) (2006: 63-4) are both more volatile and on average grow faster than the WPI. This would make the Goodhart's Law problem even worse. A composite index, including for example the WPI and core inflation, might be more promising.

9 ABS 5204.0 table 5, ABS 5206.0 tables 3 and 7. 


\section{Other options}

Since a permanent level targeting regime appears to be unsuitable for Australia unless a better target variable can be constructed, other options for monetary policy at the zero lower bound require consideration.

A higher inflation target has been advocated by Bernanke (1999), Rogoff (2008), Mankiw (2009), and Blanchard (Davis 2010). The logic - higher expected inflation lowers real interest rates and raises expected real incomes - is similar to that of level targeting, while being a less radical change from the existing policy regime. It has the disadvantage that higher inflation is not restricted to periods of catch-up (although Akerlof et al. (2000) argue that inflation of up to 4 per cent is optimal, even ignoring the zero lower bound). Against this, it has the major advantage of letting bygones be bygones when the economy is hit by supply shocks. A higher inflation target might lack credibility if it is initiated at a time when the central bank is already undershooting its target. The experience of Japan under 'Abenomics', however, suggests that even a modest increase in the inflation target may be helpful, especially if combined with other measures. Tulip (2014) has argued that activist fiscal policy may substitute for a higher inflation target; conversely, any constraint on fiscal policy would make it more desirable.

For a small, open economy, the exchange rate is a logical alternative to interest rates as a policy instrument. Svensson's (2003) 'foolproof' policy combines a price level target with a crawling exchange-rate peg that is abandoned when the target is reached. The price level target makes a lower nominal exchange rate credible, while the currency peg demonstrates the central bank's commitment to the target. As with any accumulation of foreign exchange, however, there is a risk of capital loss. ${ }^{10}$

A similar approach could be applied to level targeting without exchange rate intervention. While even a core price index may not be suitable for level targeting on a long-term basis, there would be less risk in employing it temporarily, particularly if the commitment is only to making up shortfalls from the target rather than reversing rises above it. Either regime could be initiated at policymakers' discretion, or automatically once the cash rate fell below a certain level.

Quantitative easing and negative interest on reserves are two expedients made possible because interest rates vary widely depending on the risk and duration of the loan, while the real costs of holding cash allow some room for negative

10 Notwithstanding this risk, the RBA has occasionally intervened in currency markets since the floating of the dollar in 1983. See, for example, www.rba.gov.au/publications/bulletin/2011/dec/7.html. 
interest to be charged on central bank reserves. 'Quantitative easing' - central bank purchase of a wider-than-usual range of assets to reduce term and risk premia - may have some effect even when short-term safe rates are at zero. The Swedish, Swiss and European central banks have demonstrated that negative interest on reserves is practical. These measures are unlikely to be much help in isolation, however. As Woodford (2012: 86) states, the effect of asset purchases, absent a change in expectations about future policy or direct allocation of credit by the central bank, is highly uncertain, and 'it would be hard to defend the use of such a policy as a signal in order not to have to make any verbal commitments about policy'. In the Australian context, Elias and Kulish (2010) are sceptical that money growth has any effect separate from shortterm interest rates, but Jones and Kulish (2011) are more positive about the use of long-term interest rates as a policy instrument. (Long rates are, however, still subject to the zero lower bound, and carry similar capital risks to exchange rate intervention.) Negative interest rates are, of course, intrinsically limited by the option of holding currency.

Forward guidance, or the issuing of contingent statements about the future path of interest rates, is by contrast explicitly designed to work through expectations. It may be seen as a less rigid (and possibly for that reason less effective) version of the commitment to more expansionary future policy inherent in level targeting or a higher inflation target. ${ }^{11}$

\section{Conclusions}

This paper has made several suggestions for policy at the zero lower bound, having argued that a permanent level targeting regime is undesirable. The general theme is that effective policy requires a clear goal for the future as much as concrete action in the present. Since there appears to be no single policy regime that is ideal for all situations, however, the zero lower bound may require some flexibility in targets as well as instruments. Options include a higher inflation target and temporary exchange rate or price level targeting. Forward guidance, quantitative easing, and negative interest rates seem of limited value on their own.

\footnotetext{
11 Arguably, forward guidance in this sense will only be effective if it implies a greater tolerance for above-target inflation. For example, a statement that 'interest rates will not rise until unemployment is below $\mathrm{x}$ per cent' is only informative if the inflation target would otherwise imply a rise in interest rates while unemployment is still above $\mathrm{x}$ per cent.
} 
Such an approach may lack the simplicity and symmetry of pure inflation or level targeting. Yet the constraint presented by the zero lower bound (and downwards nominal wage rigidity) is by definition asymmetric and statecontingent. Perhaps policy should be, too.

\section{References}

Akerlof, G., Dickens, W. and Perry, G. 2000, 'Near-Rational Wage and Price Setting and the Long-Run Phillips Curve', Brookings Papers On Economic Activity 1: 1-44.

Bank of England 2013, 'Monetary policy trade-offs and forward guidance'. Available at: www.bankofengland.co.uk/publications/Documents/inflationreport/2013/ irl3augforwardguidance.pdf.

Berg, C. and Jonung, L. 1999, 'Pioneering price level targeting: the Swedish experience 1931-1937', Journal of Monetary Economics, 43(3): 525-51.

Bernanke, B. 1999, 'Japanese Monetary Policy: A Case of Self-Induced Paralysis?', paper presented to the Boston ASSA meetings, 9 January 2000. Available at: www.princeton.edu/ pkrugman/bernanke_paralysis.pdf.

Bewley, T. 1999, Why Wages Don't Fall During A Recession, Harvard University Press, Cambridge, MA.

Canzoneri, M., Cumby, R. and Diba, B. 2005, 'Price- and wage-inflation targeting: variations on a theme by Erceg, Henderson, and Levin', Proceedings, Board of Governors of the Federal Reserve System: 181-215.

Coletti, D., Lalonde, R., Masson, P., Muir, D. and Snudden, S. 2012, 'Commodities and Monetary Policy: Implications for Inflation and Price Level Targeting', Bank of Canada Working Paper 2012-16.

Crafts, N. 2013, 'Escaping liquidity traps: Lessons from the UK's 1930s escape', VoxEU, 12 May. Available at: www.voxeu.org/article/escaping-liquiditytraps-lessons-uk-s-1930s-escape.

Davis, B. 2010, 'Q\&A: IMF's Blanchard Thinks the Unthinkable'. Available at: blogs. wsj.com/economics/2010/02/11/qa-imfs-blanchard-thinks-the-unthinkable/.

de Brouwer, G. and O’Regan, J. 1997, 'Evaluating Simple Monetary-policy Rules for Australia', RBA conference paper. Available at: www.rba.gov.au/ publications/confs/1997/de-brouwer-oregan.pdf. 
Dickens, W., Goette, L., Groshen, E., Holden, S., Messina, J., Schweitzer, M., Turunen, J. and Ward, M. 2007, 'How Wages Change: Micro Evidence from the International Wage Flexibility Project', Journal of Economic Perspectives 21(2): 195-214.

Elias, S. and Kulish, M. 2010, 'Direct Effects of Money on Aggregate Demand: Another Look at the Evidence', RBA Research Discussion Paper 2010-05.

Erceg, C., Henderson, D. and Levin, A. 2000, 'Optimal monetary policy with staggered wage and price contracts', Journal of Monetary Economics 46(2): 281-313.

Freebairn, J. and Corden, M. 2013, 'Vision Versus Prudence: Government Debt Financing of Investment', Melbourne Institute Working Paper No. 30/13.

Givens, G. 2009, 'Which price level to target? Strategic delegation in a sticky price and wage economy', Journal of Macroeconomics 31(4): 685-98.

HM Treasury 2013, 'Review of the monetary policy framework'. Available at: www.gov.uk/government/publications/review-of-the-monetary-policyframework.

Jones, C. and Kulish, M. 2011, 'Long-term Interest Rates, Risk Premia and Unconventional Monetary Policy', RBA Research Discussion Paper 2011-02.

Kahn, S. 1997, 'Evidence of Nominal Wage Stickiness from Microdata', American Economic Review 87(5): 993-1008.

Krugman, P. 1998, 'It's Baaack: Japan's Slump and the Return of the Liquidity Trap', Brookings Papers on Economic Activity 2: 137-205.

Mankiw, G. 2009, 'It May Be Time for the Fed to Go Negative', New York Times, 18 April.

Mankiw, G. and Reis, R. 2003, 'What measure of inflation should a central bank target?', Journal of the European Economic Association 1(5): 1058-86.

McKibbin, W. 1997, 'Which Monetary Policy Regime for Australia?', RBA conference paper. Available at: www.rba.gov.au/publications/confs/1997/ mckibbin.pdf.

- 2015, 'Central banks must target growth not inflation', Australian Financial Review, 15 January.

Mishkin, F. and Woodford, M. 2013, 'In Defence of the Fed's New Interest-Rate Policy', Wall Street Journal, 6 January. 
Orphanides, A. 2003, 'The quest for prosperity without inflation'. Journal of Monetary Economics 50(3): 633-63.

Quiggin, J. 2012, 'Inflation target tyranny', Australian Financial Review, 19 January.

Reserve Bank of Australia 2006, Statement on Monetary Policy, February 2006.

Rogoff, K. 2008, 'Inflation is Now the Lesser Evil', Project Syndicate, 2 December. Available at: www.project-syndicate.org/commentary/inflation-is-now-thelesser-evil.

Romer, C. 2011, 'Dear Ben: It's Time for Your Volcker Moment', New York Times, October 29.

— 2013, 'It Takes A Regime Shift: Recent Developments in Japanese Monetary Policy Through the Lens of the Great Depression', speech given at the NBER Annual Conference on Macroeconomics, 12 April.

Sheehan, P. and Gregory, B. 2013, 'The Resources Boom and Economic Policy in the Longer Run', ANU Centre for Economic Policy Research Discussion Paper No. 683.

Sumner, S. 1993, 'Colonial Currency and the Quantity Theory of Money: A Critique of Smith's Interpretation', Journal of Economic History 51(1): 139-45.

— 1995, 'Using Monetary Policy to Target a Nominal Wage Index', Journal of Economics and Business 47(2): 205-15.

Svensson, Lars E.O. 2003, 'Escaping from a Liquidity Trap and Deflation: The Foolproof Way and Others', Journal of Economic Perspectives 17(4): 145-66.

Tulip, P. 2014, 'Fiscal Policy and the Inflation Target', RBA Research Discussion Paper 2014-02.

Woodford, M. 2003, Interest and Prices, Princeton University Press, Princeton.

- 2012, 'Methods of Policy Accommodation at the Interest-Rate Lower Bound', presented at the Jackson Hole Symposium. Available at: kansascityfed.org/ publicat/sympos/2012/mw.pdf. 
This text is taken from Agenda, Volume 22 - Number 1, 2015, edited by William Coleman, published 2015 by ANU Press, The Australian National University, Canberra, Australia. 